\title{
Nationalism in Border Community: Temajuk, Sambas District, West Kalimantan, Indonesia
}

\author{
Iva Rachmawati and Machya Astuti Dewi \\ Universitas Pembangunan Nasional "Veteran" Yogyakarta
}

\begin{abstract}
The low level of nationalism is one of the noticeable problems that often occur in the border-region, and the Indonesian border in Kalimantan witnesses the same problem. This issue arises because border-areas tend to be underdeveloped areas, with inadequate development and facilities. The lack of state attention to border communities is claimed to be the reason for people's disloyalty toward the state. Additionally, national border violations and illegal trade are increasingly being considered as an indicator of the low levels of nationalism prevailing among border communities. This research attempts to examine how the border communities in Temajuk have built their attachment to their living environment in a way that would enable them to reinterpret the nationalism of border communities. In doing so, this study uses a descriptive-qualitative approach. Data collections have been obtained from document-tracking and interviews with local district/village officers, Badan Pengelola Perbatasan Daerah officers, border military guards, and several residents in Temajuk. The finding indicated that bonding and emotional experience encourage citizens to remain committed to being Indonesian citizens although neighboring countries have better development and prosperity levels. Contrastingly, nationalism promotes a stronger territorial awareness, which then encourages the proborder welfare policies.
\end{abstract}

\section{Keywords}

Nationalism; Border; Place Attachments; Emotional Bonding; Territorial Awareness

\section{Introduction}

Nationalism is one of Indonesia's border issues, especially on the Kalimantan border (Indonesia-Malaysia border). The other border issues that often appear in the Indonesia-Malaysia border are illegal logging, illegal trade, illegal farming, and border violations. The point of nationalism often appears on borders because boundaries are not merely "visible lines" in space or on a map.

\footnotetext{
* Iva Rachmawati (corresponding author) and Machya Astuti Dewi Department of International Relation, Faculty of Social and Politcal Science, Universitas Pembangunan Nasional "Veteran" Yogyakarta, Jl. Babarsari No. 2, Tambakbayan, Special Region of Yogyakarta, Indonesia; iva.rachma@gmail.
} 
They are also complex social constructions, with many different meanings and functions being imposed on them(Haselsberger 2014). The theoretical critique of John Agnew, a political geographer, indicates the availability of a critical dimension to what he calls "territorial traps," which are interpreted to be a state-centered perspective, where the perspective places the state's territorial boundaries as self-limiting subjects.

Territorial traps rest on three assumptions, namely, sovereignty, security, and the fact that the political life of a modern state requires limited territorial space. Second, there is a fundamental conflict between the internal and the external issues that a country could be facing. Third, the territorial state functions as a geographical vessel for a modern society whose state boundaries coincide with boundaries formed by political and social processes. This thinking shows that the world is composed of a delimited and mutually exclusive territory with its own collective identity. Thus, the main contours of society are shaped by the need to coincide with state boundaries (Paasi 2009:6-7). According to the "liberal" paradigm, states are not the only, and sometimes not even the main, political actors; further, the primary function of state borders is to ensure contact between the neighboring countries and facilitate their interaction.

Hence there is a need for a speedy resolution of border conflicts and the comprehensive development of transborder infrastructure (Sevastianov et al. 1., 2015:39). States are not the only political actors who determine the boundary. The border would be very dynamic, depending on the border-residents' interaction and perception (Markuszewska et al. 1., 2016; Kurowska-Pysz and Szczepa'nska- Woszczyna, 2017). Their ease of activity and prosperity also determine the establishment of the border. Thus, the state borders' primary function is to ensure contacts between neighboring countries and facilitate their interactions (Sevastianov. et al. 2015:39).

The liberal views on borders emphasize the role and importance of developing border-areas in promoting border residents' welfare. The low development in border-areas affects community welfare, and this could result in low nationalism among the border community. The issue of low nationalism in the border community also drives vulnerability in the Indonesia-Malaysia border conflict. Indonesians are quick to suspect that Malaysians are the leading cause of the low levels of nationalism found among communities living on Indonesian borders, and this is because of Malaysian social policies toward border residents. Malaysia provides education and health facilities for border residents in Indonesia if they are willing to accept a Malaysian ID card. Meanwhile, the border conditions found in the Indonesia-Malaysia border in Kalimantan are still inferior; this is especially true of the road 
conditions. Access is still minimal and for this reason, other public facilities such as electricity, health, schools, and communications are in scarce-supply. The situation is undoubtedly a sensitive matter for Indonesia since it may trigger disputes easily.

Snyder (1964) stated that "Nationalism is a condition of mind, feeling, or sentiment of a group of people living in a well-defined geographical area, speaking a common language, professing a literature in which the aspirations of the nation have been expressed, being attached to the common traditions, and, in some cases, having a common origin." More than just the closeness that grows from the same language, tradition, and place of residence, Hans Kohn (1965:9) describes nationalism as "a state of mind, in which the supreme loyalty of the individual is felt to be due to the nation-state". In line with the opinion of Kohn, Gray (2010), and Davidov (2009), regard nationalism as a condition of the soul possessed by someone in the form of love, loyalty, pride, and respect. In simple terms, nationalism is an emotion that binds a person to his nation. Referring to Hertz in Taniredja (2013:199), nationalism as an ideology plays three functions: binding on all classes of citizens, uniting the nation's mentality, and strengthening citizens' influence toward policies adopted by the state. Nationalism is an adhesive tool for social cohesion to maintain the existence of the state and nation. The term "low nationalism" indicates the lesser intensity of bonding people have with their nation and it is indicated by disloyalty to the country.

The issue of disloyalty and a low pride toward one's nation often arises at the border. Economic and social activities that tend to lean on neighboring countries are often the reason for the low level of nationalism prevailing among communities living at the border. Several studies have shown that the backwardness and the lack of the state's proborder welfare policy are the leading causes of these problems. Rizki and Merdekawati (2016) firmly stated that the lack of public facilities and road access could injure morality and destroy border nationalism. On the other hand, the research of M. Safitri (2013) — the research was carried out with the sample of the Badau community (West Kalimantan, Indonesia)—shows the emergence of a "new identity," which is quite alarming for the existence of "Indonesianness" and the nationality of the Badau community. The weak role and dysfunction of the state and the community's high dependence on neighboring countries have led to the emergence of new norms that are more "practical" and relevant in residents' daily lives. The state's weak role on the border community impacts the existence of, as well as leads to contraction in, the number of Badau residents' identity as Indonesians. In their daily lives, according to 
these records, the Badau people not only tend to underestimate the rules set by the state but also do not really care about their nationality and do not even show pride as being Indonesian citizens. The way Badau people show their nationality is explained by Abdullah and Sari (2014) through identity construction, which is used interchangeably according to their needs. The huge dependence on Malaysia and the lack of development has encouraged the Badau community to be pragmatic. Although finding nationalism that is still considered both in terms of politics and ideology, Mansyah's (2017) research is also concerned about the fading of Sanggau's nationalism if the government does not immediately foster awareness of nationalism in borderregions through adoption of the appropriate policies.

According to Anderson (2001: 214-215), the lower sense of belonging and togetherness has caused low nationalism. The absence of a proborder community policy and adequate public facilities - unfortunately found to be common in Indonesia-was the leading cause of the common sense of belonging in the border-area. In general, border-areas in Indonesia are still underdeveloped and far from the target of government policies. The security approach has hampered the state's perspective in managing border-areas. However, Skeldon (1999) argues that border conditions have different characteristics and that it is crucial to understand local border strategies through the level of ethnic and cultural similarities among people at the border. For border residents, interactions such as cross-border trade, smuggling, labor migration, socializing, and visiting friends and relatives on the opposite side are the main characteristics of their daily transnational life. These characteristics are not related to loyalty to the nation. That is how border residents live their everyday life.

Temajuk Village, West Kalimantan, an under developed territory, experienced a high dependence on Malaysia. Owing to the isolation and inequality with the neighboring village in Malaysia and Temajuk Village (the border village which covers the Camar Bulan area), the residents were often suspected of not having strong nationalism toward their country and of preferring to become a Malaysian citizen. The accusation is brought against them when issues arise and local governments consequentially begin to expose the conditions of their area. The absence of roads and the lack of electricity and schools until 2011 seemed to be the right reason. In an interview with the Regent of Sambas in April 2019, he explained that the issue of annexation was a blessing. A number of the central political elite began to visit and promised better development. The construction of the Paloh-Temajuk road started in 2011, and the electricity installations and senior high schools were also developed. 
Besides development of public facilities by the central government, several private tourism investments made Temajuk as the new tourist destination. This article aims to examine how the border communities in Temajuk built their attachment to their living environment to reinterpret border communities' nationalism.

\section{Method}

The study used a qualitative approach to understand the nationalism amongst residents who live along the border-area. The research collected data from field observations and interviews with local officers in Temajuk Village and local officers in Paloh District who understand the border-area's situation. The study conducted interviews with several residents in Temajuk who carried out illegal trade and illegal farming in the conflict area. The reason for these residents' alleged dissent is vital in arriving at an understanding of how they interpret their citizenship and nationalism. Data was also collected from secondary resources, such as annual reports and relevant journals. All data is categorized according to the relevant topics analyzed descriptively.

\section{Temajuk Village}

Temajuk Village is a village in Paloh District, Sambas Regency, West Kalimantan Province. Together with the other two other villages, namely Maludin and Sempadan, Temajuk is an isolated area because of the lack of public facilities such as roads, electricity, transportation, and communication. The remote condition has made Temajuk Village residents has put them in a situation wherein they are forced to contemplate whether they should/want to go to Paloh District or Sambas Regency to obtain their basic needs or for trade. Inadequate road access creates difficulties for them in reaching other areas. To get to the district area, residents need 3 hours if the weather is not raining and the road is dry. The residents had to pass the beach to reach other places before the government built the road. They were required to wait for the sea to recede to cross the coast. Further, if the vehicle is damaged, they could only wait for help from residents who passed by.

The residents' difficulties in obtaining basic needs and selling their products such as rubber and pepper encouraged residents to get several essential commodities such as rice, sugar, oil, flour, gas, and pulses from Malaysia. The border residents could obtain basic needs and social facilities from Malaysia, such as health and education services. It is not uncommon for Indonesians to find work in Malaysia, such as farmers and carpenters. This situation happens because conditions in Malaysia are far better than those in border-areas in 
Indonesia. They have better public facilities like roads, communication, electricity, education, and health facilities. The Malaysian government also provides subsidies for several basic needs, and Indonesian citizens also enjoy these subsidies because they shop for necessities from Kampong Telok Melano Village in Malaysia.

Temajuk Village is directly adjacent to Kampong Telok Melano Village in Sarawak, Malaysia. The condition of the village is almost the same, i.e., isolated. The residents must go by sea if they want to leave the village. Residents even need up to 8 hours from the Sematan Pier in Lundu to reach Kampong Telok Melano Village. However, in 2015, because of the Sarawak Pan Borneo Highway Project, excellent road access was facilitated from Lundu in Sarawak to Kampong Telok Melano Village. The residents do not have to go by sea. Kampong Telok Melano Village has become a tourist destination that is crowded with Malaysians because the road access from Sarawak to Telok Melano Village has been well-built. Unfortunately, the opposite condition found that Temajuk village became a traditional village based on Regent Decree Number 186 dated June 5, 2002.

However, for better welfare, the community can explore much natural potential. The existing forest land covers approximately $1,550 \mathrm{ha}$, and currently, producing honey bees is quite adequate. Moreover, dry land covers an area of 1,000 ha. On this land, rubber, coconut, taro, peanuts, and fruits (bananas, watermelons, durians, and many others) plantations are done. The coastal land in the Temajuk Village is approximately $26 \mathrm{~km}$ long, which produces fish, lobster shrimp, jellyfish, and baby turtles (Huruswati et al., 2012). Temajuk village is inhabited by 557 households, which are spread in Temajuk Village with 252 families (45.2\%). Further, in Maludin Village, there are 158 families (28.4\%) and 147 families in Sempadan Village or 26.4 $\%$ (Temajuk village office 2015). Most (85.65\%) of the population work as farmers (especially pepper farmers), and a small number become fishermen (Temajuk Village Office 2015).

Unfortunately, this potential has not been supported by adequate infrastructure. The electricity supply has not been able to serve all residents in Temajuk. Electricity is available from 06:00 am to 06:00 pm only (Yunando and Sutriyatna, 2018). In recent years, residents have started to get electricity from 04:00 pm (Herlin, local officer, in-depth interview, March 2019). Thus, village services can start their working-hours earlier. Likewise, the road as the primary access for residents to carry out economic activities has not been well developed. 
In 2012, the government built a $47 \mathrm{~km}$ road facility with $8 \mathrm{~m}$ to connect Temajuk Village with Paloh District. However, until April 2019, the road has not been completed. It is dusty during the dry season and becomes muddy and will be difficult to traverse in the rainy season. However, the unfinished road contributes positively to Temajuk residents because they do not need to cross the coast and wait for the tides to reach Paloh District. Yet, the residents usually do not dare to go to Paloh District in the rainy season. If the situation forced them to go, residents must prepare 300-400 thousand rupiah for expenses if the motorcycle breaks down or other obstacles are faced, such as overnight stay on the beach (news.detik.com, 2012). Until the research was carried out, the road had not been finished yet. However, this condition was better than earlier because Temajuk Village residents had to wait for the tide to recede to reach the coast to contact Paloh District.

There was a conflict area between Indonesia and Malaysia at Camar Bulan, which covers an area of 1,499 ha. The place mentioned was bordered by hooks number A.88 - A.156 and is known as enclave Camar Bulan. The borderline point had been made in 1976 and was profoundly studied for two years by Indonesia. Then, the borderline point was agreed in the $\mathrm{MoU}$ of the year 1978. The MoU is then brought into an issue when the watershed method could not address the borderline. The failure of watershed methods became the reason for Indonesia to review the agreement to be canceled owing to a fundamental circumstantial reason that referred to Article 62, Verse lof VCLT (Vienna Convention on the Law of Treaties) 1969.

Figure 1. Camar Bulan Enclave/Tanjung Datu A88-A156 (The one of Outstanding Border Dispute before 2011 Agreement). Source: Purwo Mursito. 2010. "Peran Arsip Dalam Mendukung Upaya Diplomasi Guna Penyelesaian Sengketa Perbatasan Camar Bulan Dan Tanjung Datu”. Jurnal Kearsipan. VOL 7/ANRI/12/2012. p. 101.

The agreement of the borderline area (particularly for enclave Camar Bulan) was administered again in 2011 by a team that consisted of the Domestic Affair Ministry, Foreign Affair Ministry, Mabes TNI (the Headquarter of the Indonesian Armed Forces), and the Geospatial Information Board. The meeting discussed determination of the territorial demarcation in Tanjung Datu (Camar Bulan A.88 - A.156). Besides, they also held a coordination meeting at the minister's level in the Ministry of Coordinator of Politic, Law, and Security led by the Minister of Coordinator of Politics, Law, and Security on October 20, 2011. This meeting mostly discussed the problem that takes place in Tanjung Datu. The session concluded that demarcation should be based on borderlines determined using watersheds that were conducted by a 


\section{Rachmawati \\ Nationalism in Border Community: ....}

joint survey in 1976 and repeated in 1978; these indicate an identical result. Therefore, Indonesia cannot cancel the MoU 1978 unilaterally.

The 2011 negotiation resulted in Malaysia's annexation of Indonesia's territory and it proved the poor coordination between central and local governments of Indonesia. On the other side, the residents are disappointed because their residential area becomes narrow. The distance between the outer border of Temajuk Village and the coastal line was only $700 \mathrm{~m}$ in 2019. The coastal erosion was not immediately tackled by the government and it continued to erode the land. The country's indifference was responded to by the resident of Temajuks by an illegal farming known as group 31. Illegal farming became an essential point for understanding nationalism in the border-area, especially in Temajuk Village.

\section{Place Attachment and Nationalism}

To understand the territorial nationalism among the residents, this research uses the place attachment concept that explains the bonds between citizens and the place where they live. The idea also describes how the attachment could stimulate territorial awareness, which drives better development of the living area. Place attachment refers to the emotional impact of one place that people are attracted to by emotional and cultural bonds. Place attachment is a symbolic relationship with the place formed by giving emotional meanings and common sense to a particular area and explaining how people perceive places and how they relate to them (Altman and Low, 1992: Stedman, 2003). The emotional bond that grows between people and their place of residence, according to Hashemnezhad et al. 1 (2012), is also encouraged when the area is meaningful and significant to people. The site has a unique identity and character to the users via its beloved symbols. In the level of identifying with the place's goals, people integrated with the area; moreover, their destinations are recognizable. The users are also delighted with these goals; thus, they have a deep attachment to the sites. The active roles existing in that place can measure the involvement of people using a location. They would like to invest their resources such as money, time, or talent in the activities of the place. Therefore, the attachment would affect the attitude, and this stage is mainly managed through the people's real manners.

Hashemnezhad et al. (2012) argue that five things encourage bonds between people and places of residence. They are physical, social, cultural, memory and experience, and personal factors. The physical condition binds the people who live in it because they are used to it. Apart from physical conditions, social situations cause a strong binding. It could be said that even when the physical 
condition does not provide sufficient access and facilities, social factors give rise to a more significant influence. Many researchers believe that place attachment is based on people's participation, social network engagement, and cultural interactions. These are more important than physical condition. Place attachment develops with positive interaction, and social compatibility with places and place-attachment powers directly relate to these communication powers and rates. At the same time, culture provides a strong foundation for bonds between people and shelter, where places are an essential part of cultural activity.

What is difficult to bargain for is the fourth factor, memory and experience. This factor makes people so attached because memory and experience build specific meanings for some individuals in a short time. "All people experienced being in a place, respecting it and concern about the lack of such things. Comprehensible and meaningful places are appropriate to support values, personal memories, and feelings rely on them. Place identity has close relations with personal identity, that 'I am here' means 'I am existing'” (Madanipour in Yazdanfar et.ll. 2013). Reflections of this feeling about people and the places they remember is made possible because the site within the area is experienced differently by each individual (Marcus, 1992).

The last factor is the personal factor. People select and attach places to their conscious tendencies that result from personal characteristics and factors. Individualism is a more important factor in social orientation and the means to develop intimacy of social communication which is known as mental identities based on initial tendencies. Place identity develops in direct experience of physical environment; therefore, it is a reflection of place of social and cultural aspects and plays an important role in growing personal character, according to Walmesley (1988). Physical conditions are not the only main factor that attaches people to their place of residence and they are the only measure to assess people's ties to a place. This was evident in the interplay of affects and emotions, knowledge and beliefs, and behaviors and actions, according to Prohansky et al. (1983). There are several other factors that bind a person to the place where he lives that are able to grow the awareness he has. Place attachment offers a view of nationalism in a slightly different way on border-areas. Mainly the borders in postcolonial countries generally split different ethnicities and divide the same ethnicity (Tirtosudarmo, 2005, 1). State borders do not always follow the dividing line between different cultural areas, languages, ethnic groups, or economic units (Lapian, 2009; cf. Ulaen et al., 2012: 61). In other words, a state border can separate a culture into two different political entities. The state boundaries in these different postcolonial 
states differ from those in European countries, giving rise to several state territorial boundaries similar to those of ethnic groups. Thus, nationalism is congruent with the same cultural ties. Kamenka (in Kamenka ed., 1973: 8-9) states that the general understanding of nationalism was obtained from the French Revolution which emphasized citizens' loyalty and love for their nation through their ties to the state. Likewise, Kleinpenning and \& Hagendoorn (1993), Coenders (2001), and Lactheva (2010) use nationalism to oversee the romantic phenomenon of nationalism and chauvinism in European countries. This understanding is not sufficient to explain nationalism in border-areas. Nationalism at the borders of postcolonial countries shows a different practice from the national spirit constructed by the state. Anderson (1983) emphasized that nationalism is more concerned with consciousness, and it is an imaginary construction of the unity of the community that is well known as a nation.

On the border, the ties that exist on border do not always grow in line with state borders. They grow along with cultures and tribes that often cross national borders. Thus, the construction of ties made by the state must go hand in hand with cultural and tribal ties on the border. Dedess's (2015) research on border communities in the Batam Islands shows that the nationalism that develops within them is "split" between mutual ties and closeness under the Malay umbrella, which can defeat the power of the state and territory ideology that separates border communities of Indonesia, Singapore, and Malaysia. Likewise, Munandar's research (2017) states that the Indonesian-Malaysian border community at the border live as Dayaks or Malays. Their non-participation in the formation of the state and many local policies encouraged strengthening their Malay or Dayak identity, whose ties are across national borders. Thus, physical, social, cultural, memory and experience, and personal factors, according to Hashemnezhad et al. (2012), establish a different nationalism on the border where nationalism intertwines with cultural and ethnic ties.

The place attachment through personal bonding of long experience of social, cultural, and physical environment could be found from the number of indepth interviews with several residents and local officers. First, the physical limitations are often the main reason for the low nationalism. However, the place of residence's difficulty can foster attachment between the residents and the place itself. Physical limitations caused by the difficulty of access do not prevent them from settling down because the natural resources offer more than they can get in other areas. Muhid, a transmigrant from Mojokerto, said he was quite happy at Temajuk because the current conditions were far better than the conditions in Mojokerto. Even raw foods are easily obtained 
at affordable prices (and they can be purchased from Kampong Telok Melano Village, Malaysia) (https://www.jpnn.com; October 2011). Although access to the other West Kalimantan region is challenging to reach from Temajuk, access to Malaysia is effortless. They can sell their crops to Malaysia and buy their needs from Malaysia. There have not been strict rules regarding crossborder activities in Temajuk-Kampong Telok Melano. Border-area residents only need an ID card to enter the border state.

The offer of better public facilities in Malaysia is one of the main factors of suspicion or opposing views on national identity. However, public facilities turned out not to be the sole factor of the residents to forgo their nationalities, but there are so many social factors to be considered. There is a perception of social discomfort in the community to become Malaysian citizens.

"Oh, belum tentu. Bibi saya udah warga negara di sana, katanya dilihat orang lebih enak kita merasakan lebih sakit tapi dia ndak mau bilang. Rupanya lebih sakit di sana, katanya. Kita ndak tau peraturannya di sana seperti apa. Tapi saya kalo pribadi saya ndak mau. Udah lama tinggal sini lah". ("Oh, not necessarily. My aunt is already a Malaysia citizen, and she said it might be seen better by other people but actually what she felt was more painful but she didn't want to say the reason. Apparently it is more painful to be there. We don't know what kind of rules are enforced there. However, I don't want it personally. It's been a long time here.".) (Herlin, in-depth interviewed, March 2019).

Even though the natural conditions are bad, residents are already familiar with the situation. Thus, natural conditions are not the main factor in eroding the nationalism of border residents. Trading and shopping for basic needs in Malaysia are not the reason for not having nationalism, although that is what many people think. What these people do is only driven by a rational choice with the consideration of convenience. Distances, costs, and facilities require them to choose Malaysia over Indonesia to fulfill their basic needs. Indepth interviews with residents reveal these arguments. They do not see other reasons beyond practicality and doing normal things.

Meanwhile, place attachments are also built-in in line with interactions that have run positively among border communities. They can resolve the problems between border residents quickly without any direct involvement being required on the part of the local government. Regular visits conducted by local officers build a supportive situation. The former head of Paloh municipality, Usman, stated that the hospitality visitation was held in order to keep the good relationship between the two states:

"Maka saya untuk menghilangkan konflik-konflik ini saya mubibah dengan tumenggungnya, imigresennya, termasuk TNI nya pokoknya 
muhibahlah.Untuk Tanjung Datu ini saya muhibah dengan dia di Melano saya kesana dengan rombongan.Ndak masalahlah saya mubibah kesana. Kalo di Sajingan memang saya lakukan muhibah dengan rombongan dari kabupaten makanya agak aman." ("So I, to diminish the conflicts, I pay a visit with the chief, immigration staff, including the army staff, for hospitality. For Tanjung Datu, I pay a muhibah visit in Melano. I went there in-group. It is not a problem for me to pay a visit. For Sajingan, I do a muhibah visit in-group, so it was safer.") (Usman, The former Paloh District Head, In-depth interviewed, at Kampong Telok Keramat, March 2019).

Social convenience is another key to the community's attachment to their place of residence. Village officials build this social convenience through hospitality visits through informal meetings. They used to call this "muhibah." The "muhibah" is very useful in solving problems that occur among citizens, such as family problems and social problems. Through "muhibah," they can also solve cross-border issues such as illegal logging, illegal trade, even drug smuggling and other violation of national borders, at the lowest level. Border issues are often considered a significant problem by those who do not live on the border. However, for those who live on the border, border problems are not as big as people imagine because they can quickly solve them through the personal relation and particular mechanisms they have.

"Hubungan personal yang dimiliki akan sangat membantu karena orangorang ini tidak merasa berbeda mereka merasa bertetangga mereka merasa bersaudara, biasa saja mereka saling main ke sini ini main ke sini mereka pinjam ke sini. Ada pernikahan antar negara ada perkelahian anak muda. Ya biasalah main bola, ejek ejek olok- olok. mereka tidak merasa mereka orang lain. Yang begitu begit ini masak iya mau diselesaikan di tingkat nasional. Ya biarkan saja selesai di akar rumput melalui lobby kopi di kantor camat" "Personal relationships are constructive because these people do not feel different. They feel like neighbors, feel like siblings, usually play here, and borrow something here. There are marriages between countries, and there is a fight between teenagers because of football competition. They are taunting... teasing they do not feel like they are someone else. These are not necessarily solved at the national level. Yes, let it finish itself at the grassroots, through the coffee lobby in the sub-district office."). (Uray Willy, District Officers in Sambas, In-depth interviewed, at Sambas, March 2019).

Emotional bonding, which is determined by cultural practices, supports the border community in social problem-solving. The Temajuk people are widely ethnic Malays. Malay culture is practiced without constraints in their daily lives, even though several Java residents live in the area. They also share the same culture that is practiced by the Kampong Telok Melano residents in 
Malaysia. Malay cultural practices can be found in traditional ceremonies such as weddings. Malay values also become a bridge for both countries' citizens to interact with each other both in social and economic relations. Indeed, they are in the same kinship. The ease in this cultural practice eventually delivers attachment between the border resident to their place.

Personal memories and experiences are other strong bonds for citizens to live. The resident who is more than 20 years old still has memories of difficulties which he/she underwent in Temajuk. However, difficulties have uniquely become a common bond. The common bond appears because the difficulties encourage them to help each other. When the rainy season comes, they need each other to fulfill their basic needs. They must save rice and other staples because it is difficult for them to get out of Temajuk Village during the rainy season. If one of the residents runs out of rice, then others will help. Likewise, they must help each other if someone is stranded on the beach because of a faulty motorcycle or even if the individual who requires help has been carried out by the sea. They do depend on one another. On the contrary, they have no sense of togetherness with several villagers who have left their village to find a better condition.

"Susah lah sekalilah waktu itu. Kalo motor bocor mana ada bengkel di pantai. Ya kita tunggulah sampai ada yang jemput. Kalo ndak ada ya digotong sakit kita jalan di pantai, belum lewat muara sungai. Wuih luar biasa. Sampai banyak orang pindah dari Temajuk. Tapi begitu Temajuk maju orang pada balik mana tanahku dulu? Kita sakit-sakit disini, mereka yang disana datang cari tanahnya disini". ("It is hard at that time. There are no motorcycle repair shops on the beach if the motorcycle was broken. Yes, we wait until someone picks us up. If no one carried it... we are sore on the beach, but not yet through the river mouth. It is amazing. Until many people moved from Temajuk, we were still facing difficult access. However, as soon as Temajuk stepped forward, the resident who had left Temajuk backs out again... and they ask, 'Where was my land first?' We are sick here, but those who left just come back and are looking for the land they have left behind"). (Ibrahim, local resident, in-depth interviewed, Camar Bulan, March 2019).

Personal factors that differ from one another also influence the ties which are continually perpetuated between residents and their places of residence. However, this research found that the border communities' characterordinarily acclimatized to the deployment of indigenous solutions to address physical limitations and the worsening of inequality — did not significantly influence the low level of territorial bonds or territorial awareness. Andriana (2015) also confirmed this by stating that citizens and local officials deeply 
understood their obligation to maintain their people's integrity and honor. The citizens and local officials reveal their opinion and attitudes toward the annexation of Indonesian territory by Malaysia.

The disappointment over the 2011 agreement that gave Camar Bulan enclave to Malaysia encouraged residents and local officers to show their different opinion. The agreement has not been ratified by the Indonesia House of Representatives yet (until 2019). However, the border-area's condition, which is threatened by abrasion and the lack of local officials' involvement in border issues, has stimulated them to take a different attitude toward the central government. The local official used the Camar Bulan annexation issue (DetikNews, 2011, TribunNews.com, 2011) to attract central government's attention to provide better development policies for the border-region.

The situation was well understood by Sambas Regency's government (Usman, The former Paloh District Head, in-depth interviewed, at Kampong Telok Keramat, March 2019). The Head of the Regional Secretariat of Sambas also confirmed that the central government only pays attention when there is turmoil.

"ika bisa saya jelaskan sedikit, kabupaten kami senang akan ribut-ribut itu, Kalo bisa maka bikin ribut terus saja. Kenapa? Karena kalo adem ayem pemerintah pusat tidak peduli. Iya, artinya kita bikin bergejolak semacam itu. Contohnya kemaren, ketika Malaysia tanpa sepengetahuan Indonesia, mendirikan mercusuar di wilayah Indonesia dan Indonesia tidak tahu. Di jaman canggih ini kan lucu? Mana logikanya, kok orang Indonesia tidak tahu. Sudah berdiri mercusuar itu, kamana petugas kita? Saya malah menyarankan pasang sekalian bendera Malaysia biar ribut. Supaya ada perhatian pemerintah pusat. Kalo engga, tidak dipedulikan. Mana siapa yang mau peduli kalo ngga ribut-ribut? Ngga peduli pak, bu. Jadi memang perlu ada hal-hal semacam itu supaya pusat juga melihat ke daerah perbatasan yang perlu diperhatikan." (If I explained, our district would be happy about the fuss. If possible, we would keep making noise. Why? Because if everything looks normal, the central government does not care. For example, when Malaysia built a lighthouse in Indonesian territory, and no Indonesian officers noticed. Isn't it funny? How come Indonesian border officers do not know? Where are they? Instead of building a lighthouse, I suggest pairs of Malaysian flags should be erected. So there is attention from the central government. Who would care if there was no fuss? So, there is a need for attention to be paid to such things to ensure that the central government also looks at borderareas." (Uray Tadjudin, the Head of Regional Secretariat of Sambas, in-depth interviewed, Sambas, March 2019).

In addition to using the annexation issue, local officials also deliberately mobilized residents to cultivate land in the disputed area, namely Camar Bulan 
Enclave. Manto Saidi, former BPPD (Badan Pengelola Perbatasan Daerah/ Local Border Management Agency) head, stated that the effort to manage the empty fields is a way to show that residents have a high motivation to manage the borderline area. At least, this will attract the central government's attention to be more careful with the farmers (Manto Saidi, Former BPPD head officer, in-depth interviewed, Pontianak March 2019).

In 2017, there was the case of Group 31. Group 31 refers to the 31 Temajuk residents/farmers who did illegal farming on Camar Bulan enclave (according to the 2011 Memorandum of Understanding between Indonesia and Malaysia, this area belongs to Malaysia). They planted rubber, pepper, banana, and several other food crops. According to the perpetrators' recognition, they were initially skeptical. However, because there was support from local officials and military members at that time, they were willing to allocate land for the farming activity conducted on Malaysian territory.

"lalu ada Danton tu datang pak Saiful dari Jogja, jadi saya koordinasi dengan beliau, beliau bilang jika masih satu kilo tiga ratus kesana. Jadi kalo saya bikin rumah ndak masalah. Jadi saya bikin. Pas ada aplusan baru ni, sesudah beberapa bulan saya ditanya, bapak kok berani bikin rumah sini ni. Ini kan tanah Malaysia? Ya kalo yang mau bongkar orang Malaysia ya ndak ada masalah ya kan tanah mereka tapi kalo orang kita ...(ragu) tapi ya udahlah. Saya jelaskan Danton yang dulu begini begini.. jadi saya ndak merasa bersalah.". " then there came Danton (military officer), Mr. Saiful from Jogja, so I coordinated with him. He asked if there was more than one kilo three hundred from Malaysia. So if I make a house, it does not matter. So I made it. After a few months, when there was a new border military officer, I was asked, why did you dare to build a house here? This is Malaysian territory. Yes, if Malaysians want to dismantle my house, it is okay because this is their territory. However, if Indonesians want to dismantle it (hesitates). Never mind. I explained to Danton that it used to be like this... so, I do not feel guilty". (Rachmad, local resident, in-depth interview, Camar Bulan, March 2019).

In 2017, the Sarawak government, Malaysia, asked residents to clear and leave their fields. Through informal negotiations between local officials of both countries, they agreed to wait until the harvest time. Thus, the policy will not disadvantage the farmers. The Sambas government also promised to assist each family who lost their fields in the Camar Bulan enclave by providing $100 \mathrm{~kg}$ of agricultural produce. From interviews conducted with several farmers in Group 31 and local officers, they had already ascertained that the ownership of the area they planted was unclear. The reason which they gave in the interviews was straightforward, "It is very unfortunate if the land is 
not cultivated by the Malaysian, then we just have to cultivate it." (residents, in-depth interview, Temajuk, March 2019). They do not know that the land belonged to the category of protected forests, for which reason Malaysia does not cultivate it. At the same time, Usman claims that managing land for basic needs rather than commercial needs is not a problem.

"Kalo Malaysia ndak ada. Jauh dia karena rakyatnya pun ndak mau tinggal di hutan kecuali rakyat kita. Banyak rakyat kita di sana. Kenapa? Ya karena iu harus kita kuasai. Artinya kita mau mengelola itu, yang ndak boleh kan mbakar ngrusak. Penduduk kita ini kan cari makan, hak asasi manusia. Kalo ngrusak apalagi untuk bisnis dijual jual na itu ndak boleh. Kalo untuk berkebun tinggal disitu ndak masalah." (Malaysia is not there, i.e., there are no Malaysian citizens living in the Camar Bulan enclave. They live far from the area because nobody wants to live in the forest except our people (Indonesians). Many of our citizens live in that area. Why? Yes, because we have to master it. That means we want to manage it, not to burn or destroy the area. Our citizens are looking for food, and it has guaranteed human rights. If they damage the area or use the area for business purposes, it is not allowed, but gardening is no problem." (Usman, the former Paloh District Head, indepth interviewed, at Kampong Telok Keramat, March 2019).

Nationalism at the Indonesia-Malaysia border shows a different face from nationalism in general in Europe. As one kin, the citizens of the two countries have emotional closeness. Coupled with economic imbalances, it is not uncommon for Indonesians to depend on the Malaysian government's economic support. However, place attachment encourages border residents to show their nationalism differently. The place attachment pushes the border community to have territorial awareness. Territorial awareness is community awareness to guard and maintain the place in which they live. This kind of awareness brings them to a situation where they have to adopt different approaches toward the central government to protect and maintain their place. Although — in general—it does not seem like nationalism, their efforts to take advantage of border issues are, in fact, able to encourage the central government to give better attention through enactment of proborder policies.

Owing to these border issues, the attention of the central government had increased recently. In 2011, the central government built a roadway that connects Temajuk village and the sub-district's capital, situated in Paloh. In the same year, they also built the necessary electricity and communication facilities for the village. Many central government officers and nongovernment organizations came to Temajuk with a promise to give more attention and develop the village of Temajuk. In 2012, 13 ministries granted aid through the National Program of Integrated Village Development Movement 
(Program Pandu Gerbang Kampung) and the Poverty Resolution Program for the State's Border Area (Pronankis). The aid-which amounted to as much as Rp. 20 billion for Program Pandu Gerbang and Rp. 200 billion for Pronankis-is expected to free Sambas from their current debilitating condition of isolation (TribunBengkayang.com., 2012). Temajuk also becomes one of the destinations for many universities, such as Tanjung Pura University, Gadjah Mada, Yogyakarta Muhammadiyah, and Pembangunan Nasional University to do their students' service programs. Besides, the arrival of some private investors has supported Camar Bulan to function as a new tourism destination. These private investors have built some resorts and an adventure-tourism package. Now, Camar Bulan has become a new tourism destination that attractively presents the beauty of the West Kalimantan coast to tourists.

\section{Conclusion}

Nationalism shows its different faces on the border. Place attachment built by personal ties delivers attitudes that are in favor of territorial awareness. In other words, a resident bound with a place develops nationalism that does not merely follow central policy but rather builds enthusiasm for an effort to bargain for policies that are proborder policy.

Isolation and inequality do not positively correlate with the common territorial bonds and territorial awareness in Temajuk Village. Social and cultural factors, memory and experience, and personal factors provide a significant contribution to territorial bonds. The dependence of Indonesian residents on Malaysia is more a pragmatic attitude that emerges from their backwardness and isolation, and cannot be exclusively attributed to a paucity in patriotic sentiment.

On the other hand, this territorial awareness emerged from a difficult situation which was demonstrated by locals to attract central government attention to carry out better development in the border-area. They have also pushed the government to support the tourism development in Temajuk Village, because tourism can be a good strategy for sustainable development in the border-area. The state's territorial awareness should have been welcomed positively by more-involving local officers and residents on border issues. Togetherness in overcoming border problems can improve the bond between the state and citizens. Further, the proborder policies will increase respect towards the state in addition to encouraging citizen compliance. 


\section{Acknowledgements}

We would like to convey our thanks to the Republic-of-Indonesia's Ministry of Research and Higher Education for providing funding for Indonesia's Border Diplomacy in Managing Border Areas: The Tanjung Datu Case Study Research. This article is part of our ongoing research into Indonesian nationalism.

\section{References}

Anderson, B. 1983. Imagine Communities: Reflection on the Origin and Spread of Nationalism. London: Verso.

Abdullah, Irwan \& Intan Permata Sari 2014. "Politik Identitas Masyarakat Perbatasan Indonesia-Malaysia: Kasus Badau di Kapuas Hulu, Kalimantan Barat. Kawistara, Vol. 4, No. 3, Desember 2014: 225-236.

Altman, Irwin \& Setha M. Low. 1992. "Human Behavior and Environments: Advances in Theoryand Research”. Place attachment. Plenum Press, New York

Andriana, Nina. 2015. "Eksistensi Kebangsaan Dan Perwujudan Keindonesiaan Di Wilayah Perbatasan Darat Indonesia-Malaysia: Kasus Kalimantan Barat”. Jurnal Penelitian Politik. Volume 12 No. 1 Juni 2015 | 83-98.

Coenders, M. 2001. Nationalistic Attitudes And Ethnic Exclusionism In A Comparative Perspective: An Empirical Study Toward The Country And Ethnic Immigrants In 22 Countries (Doctoral dissertation, Catholic University Nijmegen, 2001).

Davidov, E. 2009. "Measurement Equivalence Of Nationalism And Constructive Patriotism In The ISSP: 34 Countries In A Comparative Perspective". Political Analysis, 17 (1), 64-82

Dedees, Adek Risma. 2015. "Melayu di Atas Tiga Bendera: Konstruksi Identitas Nasionalisme Masyarakat Perbatasan di Kepulauan Batam”. Jurnal Ilmu Sosial dan Ilmu Politik Volume19, Nomor 2, November 2015 (141-153) ISSN 1410-4946.

Gray, G. D. 2010. “Teaching Patriotism In America's Public Schools”. Policy, Practice, and Debate Studies in Language and Literature, 29 (2), 1-19.

Hashemnezhad, Hashem, Ali Akbar Heidari \& Parisa Mohammad Hosein. 2013. "Sense of Place" and "Place Attachment" (A Comparative Study) International Journal of Architecture andUrban Development Vol. 3, No. 1, Winter 2013

Hidalgo, M.C., \& Hernandez, B. 2001. "Place Attachment: Conceptual and Empirical Questions". Journal of Environmental Psychology, 21, 273-281

Huruswati, I., Kurniasari, A., Purwanto, A. B., \& Sabeni, M. 2012. Evaluasi Program Pembangunan Provinsi Kalimantan Barat. Jakarta: P3KS Press.

Kamenka, Eugene (ed.). 1973. Nationalism, The Nature and Evolution of an Idea. Canberra: ANU Press.

Kohn, Hans. 1965. Nationalism: Its Meaning and History Princeton, N.J.: D. Van Nostrand Co.

Kurowska-Pysz, Joanna and Katarzyna Szczepa'nska-Woszczyna. 2017. “The Analysis of the Determinants of Sustainable Cross-Border Cooperation and Recommendations on Its Harmonization”. Sustainability, 9, 2226; doi:10.3390/su9122226. 


\section{Journal of Nationalism, Memory \& Language Politics 15(1)}

Latcheva, R. 2010. "Nationalism Versus Patriotism, Or The Floating Border? National Identification And Ethnic Exclusion In Post-Communist Bulgaria". Journal of Comparative Research in Anthropology and Sociology. 1 (2), 187-216.

Mansyah, Agus. 2017. "Nasionalisme Masyarakat Indonesia Di Perbatasan Dan Dampaknya Terhadap Kedaulatan Negara (Studi Di Kabupaten Sanggau, Kalimantan Barat) “.Jurnal Prodi Peperangan Asimetris, Desember 2017 | Volume 3 Nomor 3.

Markuszewska, Iwona, Minna Tanskanen,and Josep Vila Subirós. 2016. "Boundaries From Borders: Cross-Border Relationships in the Context of the Mental Perception of a Borderline - Experiences from Spanish-French and Polish-German Border Twin Towns”. Quaestiones Geographicae 35(1):105-119

M. Safitri, Ririh. 2013. Disfungsi Negara di Wilayah Perbatasan: Studi tentang Melemahnya Nasionalisme di Badau, Kecamatan Badau, Kabupaten Kapuas Hulu, Kalimantan Barat. Skripsi. Yogyakarta: Universitas Gajah Mada

Proshansky, H. M., Fabian A. K., \& Kamikoff, R. 1995. "Place Identity: Physical World Socialisation Of The Self”. In Linda N. Groat (Ed.) Giving Places Meaning, Reading In Environmental Psychology. Academic Press, London.

Sevastianov, Sergei V, Jussi P. Laine, and Anton A. Kireev (ed). 2015. Introduction to Border Studies. Vladivostok: Dalnauka, ISBN 978-5-8044-1579-3

Snyder, Louis L. (ed.), 1964. The Dynamics Of Nationalism: Readings In The Meaning And Development. D. van Nostrand Company, Inc., Princeton, N.J.

Stedman, R.C. 2003. "Is It Really Just A Social Construction: The Contribution Of The PhysicalEnvironment To Sense Of 12 Place". Society and Natural Resources, 16(8):671-685

Taniredja, T. 2013. Konsep Dasar Pendidikan Kewarganegaraan. Yogyakarta: Penerbit Ombak.

Yazdanfar, Seyed Abbas, Ali Akbar Heidari Nazgol Behdadfar \& Eskandari. Mohammad. 2013. "Effect Of Place Attachment In Creating Sense Of Place Case Study: Tajrish Old Bazaar And New Commercial Center". Research Journal of Applied and Basic Sciences. Vol., 4 (4), 855- 862, 2013.

Yunando \& Sutriyatna. 2018. "Studi Microgrid System Menuju Pembangunan Desa Mandiri Energi Di Desa Temajuk Kabupaten Sambas”. Jurnal ELKHA Vol.10, No 1, Maret 2018.

- - - . 2011. "Desa Temajuk, Wilayah di Perbatasan Kalbar yang Rawan Dicaplok Malaysia”. JPNN 24 Oktober 2011. https://www.jpnn.com/news/desa-Temajuk-wilayah-di- perbatasan- kalbar-yang-rawan-dicaplok-malaysia Retreieved May 2019.

- - - - . 2011. “TB Hasanuddin: Kenapa Kita Mengalah Pada Malaysia?”. Tribunews.com. https://www.tribunnews.com/nasional/2011/10/10/tb-hasanuddin-kenapa-kita-mengalahpada-malaysia. Retreieved May 2019.

- - - - . 2011."Mengambil Lagi Camar Bulan Dari Malaysia”. Antaranew.com. https:// www.Antaranews.Com/Berita/279231/Mengambil-Lagi-Camar-Bulan-Dari- Malaysia. Retreieved May 2019.

- - - - . 2011. "Malaysia Caplok Wilayah RI di Camar Bulan, Kalimantan Barat”. DetikNews. https://News.Detik.Com/Berita/D-1739839/Malaysia-Caplok-Wilayah-Ri-DiCamar- Bulan-Kalimantan-Barat. Retreieved May 2019. 
- - - - . 2011. "Patok Perbatasan RI di Camar Bulan Dihancurkan Malaysia”. TribunNews. com. https://www.tribunnews.com/regional/2011/10/16/patok-perbatasan-ri-di- camar-bulan-dihancurkan-malaysia. Retreieved May 2019.

Herlin, in-depth interviewed, March 2019.

Ibrahim, in-depth interviewed, March 2019.

Usman, in-depth interviewed, Macrh 2019.

Manto Saidi, in-depth interviewed, March 2019.

Rachmad, in-depth interviewed, March 2019.

Uray Tadjudin, in-depth interviewed, March 2019. 